Evensen, N. M., Hamilton, P. J. \& O'Nions, R. K. 1978: Rare-earth abundances in chondritic meteorites. Geochim. cosmochim. Acta 42, 1199-1212.

Garde, A. A., Hall, R. P., Hughes, D. J., Jensen, S. B., Nutman, A. \& Stecher, O. 1983: Mapping of the Isukasia sheet, southern West Greenland. Rapp. Grønlands geol. Unders. 115, 20-29.

Hall, R. P. 1977: The Precambrian geology of the Kangangûp tasia area, Fiskenæsset, southern West Greenland. Unpublished M.Phil. thesis, Council for National Academic Awards.

Hall, R. P. 1981: The Archaean geology of Ivisârtoq, inner Godthåbsfjord, southern West Greenland. Unpublished Ph.D. thesis, Council for National Academic Awards.

Hall, R. P., Hughes, D. J. \& Friend, C. R. L. 1985: Geochemical evolution and unusual pyroxene chemistry of the MD tholeiite dyke swarm from the Archaean craton of southern West Greenland. $J$. Petrol. 26(2), 253-282.

Hall, R. P., Hughes, D. J. \& Friend, C. R. L. 1986: Complex sequential pyroxene growth in tholeiitic hypabyssal rocks from southern West Greenland. Mineralog. Mag. 50 (in press).

Irvine, T. N. \& Baragar, W. R. A. 1971: A guide to the chemical classification of common volcanic rocks. Can. J. Earth Sci. 8, 523-548.

Kalsbeek, F. \& Taylor, P. N. 1985: Age and origin of early Proterozoic dolerite dykes in South-West Greenland. Contr. Mineral. Petrol. 89, 307-316.

Kuroda, N., Shiraki, K. \& Urano, H. 1978: Boninite as a possible calc-alkaline primary magma. Bull. Volcanol. 41, 563-575.

Nelson, D. R., Crawford, A. J. \& McCulloch, M. T. 1984: Nd-Sr isotopic and geochemical systematics in Cambrian boninites and tholeiites from Victoria, Australia. Contr. Mineral. Petrol. 88, 164-172.

Pearce, J. A. \& Cann, J. R. 1973: Tectonic setting of basic volcanic rocks determined using trace element analyses. Earth planet. Sci. Lett. 19, 290-300.

Rivalenti, G. 1975: Chemistry and differentiation of mafic dykes in an area near Fiskenæsset, West Greenland. Can. J. Earth Sci. 12, 721-730.

Wood, C. P. 1980: Boninite at a continental margin. Nature 288, 692-694.

Department of Geology, Portsmouth Polytechnic, Burnaby Road, Portsmouth PO1 $3 Q L$, U.K.

\title{
On the occurrence of scheelite in the Archaean Malene supracrustal rocks, southern West Greenland
}

\author{
Peter W. Uitterdijk Appel and Adam A. Garde
}

Scheelite in the Godthåbsfjord area (fig. 1) was found in heavy mineral concentrates from stream sediments in 1982, and in situ scheelite was discovered in 1982 on Stor $\emptyset$ in Godthåbsfjord (Appel, 1983a). During 1983 further work was carried out on the islands of Storø and Sermitsiaq in Godthåbsfjord and on the Store Malene mountain next to Nuuk (Godthåb), as a result of which several scheelite-bearing horizons were found (Appel, 1984). During 1985 a detailed mapping programme was carried out on Store Malene by $A$. A. Garde. Subsequently, exposures on Store Malene as well as the island of Simiútat south 
Fig. 1. Index map of the area around Nuuk, showing major outcrops of Malene supracrustal rocks (black).

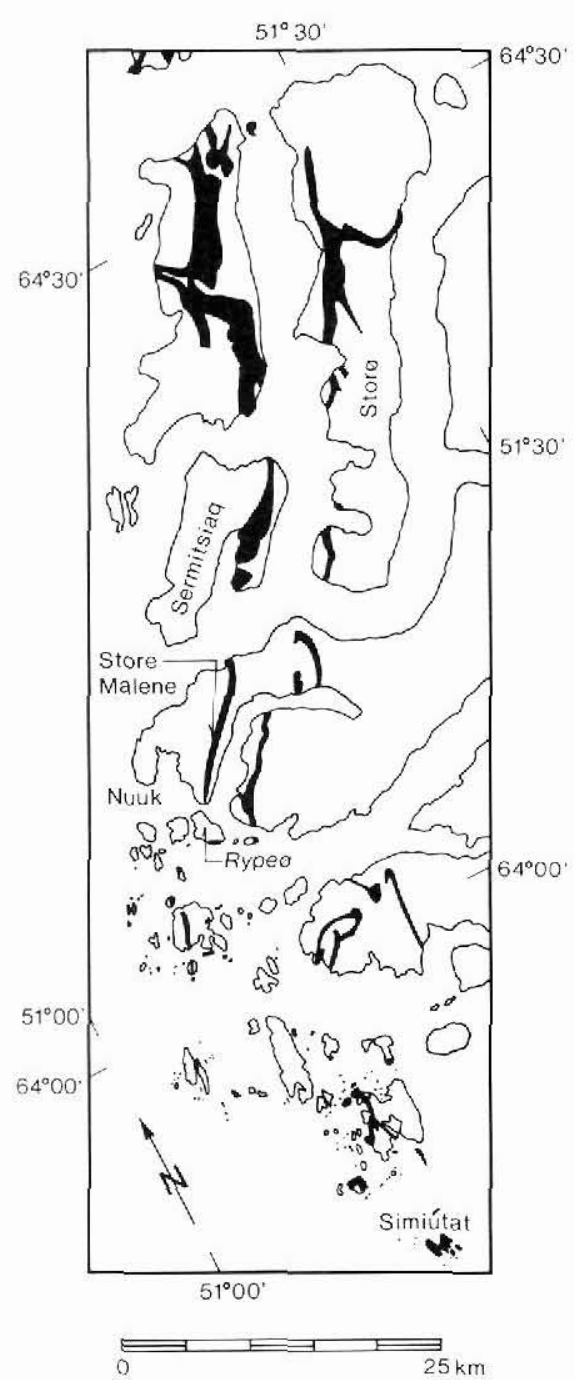

of Nuuk were investigated by ultra-violet light. A similar survey has been carried out by Olsen (this volume) on the island of Sermitsiaq.

The following report is mainly based on field observations combined with investigation of a few thin sections. Laboratory work has been confined to X-ray identification of scheelite in four samples from Store Malene and one sample from Simiútat.

\section{General geology}

The area between Godthåbsfjord and Buksefjorden is part of the Archaean basement in southern West Greenland; Bridgwater et al. (1976) and Chadwick \& Coe (1983) give general accounts of the geology. The oldest rocks in the area are the Akilia supracrustal rocks 
(McGregor \& Mason, 1977) equivalent to the $c .3750$ Ma Isua supracrustal rocks at Isukasia north-east of Godthåbsfjord. The Akilia rocks crop out as enclaves in the Amitsoq gneisses with Rb-Sr whole-rock ages around $3700 \mathrm{Ma}$. The Malene supracrustal amphibolites and metasediments, which form extensive outcrops in the Archaean basement, were tectonically intercalated with the Amîtsoq gneisses and intruded by voluminous Nâk gneisses at the next major continental crust forming event around 3000-2800 Ma. The Qôrqut granite complex in Godthåbsfjord (Friend et al., 1985), which formed by remobilisation of older gneisses, intruded the then stabilised continental crust at c. $2550 \mathrm{Ma}$ and represents the latest major phase of igneous activity in the area. The area has been repeatedly deformed and metamorphosed under amphibolite (and locally granulite) facies conditions prior to the intrusion of the Qôrqut granite complex.

\section{Supracrustal rocks at Store Malene}

The Store Malene mountain, type locality for the Malene supracrustal rocks (McGregor, 1973; see also e.g. Beech \& Chadwick, 1980; Dymek et al., 1983; Nutman \& Bridgwater, 1983), mainly consists of homogeneous Nûk tonalitic gneisses, in which a c. $500 \mathrm{~m}$ thick segment of Malene metasedimentary and metavolcanic rocks crops out along the north-east trending ridge of the mountain. The Malene rocks have intermediate to steep north-westerly dips, and can be crudely divided into a structurally lower unit dominated by various metasedimentary rocks with intercalations of amphibolites, and an upper unit almost entirely consisting of amphibolite. Numerous simple pegmatite bodies have intruded the supracrustal rocks and their contacts with the Nûk gneisses, but have themselves been deformed and probably predate the Qôrqut granite complex. The contacts between Malene rocks and Nûk gneisses are tectonic, with a thin layer of sheared-out and talcose ultrabasic rocks at the north-western contact. The Malene rocks are very strongly deformed and evidence of primary structures or direction of younging has not been found.

The metasedimentary rocks which are best exposed along the south-eastern side of the ridge consist of metapelitic quartz-plagioclase-biotite rocks, biotite-garnet schists, quartzplagioclase-sillimanite paragneisses, locally grading into pale greenish, fine-grained (presumably fuchsitic) quartzites, and cordierite-rich rocks which, besides quartz and plagioclase, contain variable amounts of biotite, chlorite, garnet, sillimanite and anthophyllite.

Black tourmaline (blue-green to olive green in thin section) is an important constituent of the metasedimentary rocks. It is frequently found in thin sections as an accessory phase, and as conspicuous tourmalinite horizons of quartz-tourmaline lenses up to $c .1 \mathrm{~m}$ thick, and tourmaline-rich layers and lenses on a scale of centimetres to decimetres in adjacent metasedimentary rocks. The tourmalinites are almost invariably found within a few metres of distinct dark green bands of metavolcanic garnet amphibolite $c .0 .1-2 \mathrm{~m}$ thick, which have sometimes gradational contacts with their metasedimentary hosts. A discordant metamorphic tourmaline-quartz vein was found, which is $c .5 \mathrm{~cm}$ thick and extends no more than a couple of metres away from the tourmalinite horizon where it originated. The tourmalinite in metasediments has been followed in the field over a strike length of $c .1400 \mathrm{~m}$ in the central part of Store Malene, and may extend further. Isoclinal folding on a scale of metres to tens of metres has repeated part of the metasedimentary pile, but it seems that there is more than one stratigraphic horizon which contains tourmalinite.

The upper half of the Malene sequence, dominated by amphibolites, has not been re- 
peated by internal isoclinal folding but has suffered more homogeneous deformation. It was possible to divide the amphibolites and their metasedimentary intercalations into a large number of individual lithologies and horizons, some of which could be traced for several kilometres along strike. The main lithologies are: homogeneous amphibolite sensu stricto sometimes containing lenses on a $10 \mathrm{~m}$ scale of (?intrusive) hornblende-blastic amphibolite, massive dark green hornblendite, quartz-banded amphibolite consisting of hornblende-plagioclase \pm diopside amphibolite with closely interspersed quartz layers a few millimetres thick, garnet amphibolite, and calc-silicate banded amphibolite, which comprises a variety of rock types that all seem to be derived from mixtures of mafic lavas and calcareous sedimentary rocks. Calcite has sometimes survived in these horizons, which are otherwise characterised by layers, lenses and irregular veinlets of diopside-clinozoisite/epidote-plagioclasesphene \pm garnet in amphibolites dominated by hornblende and plagioclase.

As in the metasedimentary rocks there are several tourmalinite zones in the amphibolites, in this case up to several metres thick. The tourmaline is most often found in discontinuous layers a few centimetres thick, fine-grained and intimately intergrown with amphibole, and difficult to discern in the field. Large tourmaline-quartz lenses are less common. The tourmalinite horizons are strictly conformable with the mapped lithological units of amphibolite and metasedimentary rocks and extend laterally on a scale of kilometres. They are, however, not confined to any particular type of amphibolite as they occur in both quartz-banded amphibolite, garnet amphibolite and calc-silicate banded amphibolite as well as in homogeneous amphibolite sensu stricto. Small discordant tourmaline-bearing veinlets in amphibolite have been found but are rare.

The amphibolites, in particular the quartz-banded and garnet amphibolites, contain metre-thick rusty zones with dispersed pyrrhotite and minor chalcopyrite. The rust zones preferably occur at the same stratigraphic horizons as tourmalinites.

\section{Scheelite occurrences}

On the island of Simiútat, south of Nuuk, a strongly folded sequence of diopside-rich calcsilicate rocks alternating with amphibolites occurs. The calc-silicate layers which are up to $0.5 \mathrm{~m}$ thick contain frequent specks of molybdenite together with small amounts of pyrrhotite and chalcopyrite, as well as very rare millimetre-sized scheelite grains and centimetresized porphyroblasts. The amphibolites in this sequence vary in appearance and only one type appears to be scheelite-bearing. It is a medium-grained somewhat rusty amphibolite layer which is up to $1 \mathrm{~m}$ thick and can be traced for about $100 \mathrm{~m}$ along strike. In this amphibolite, appreciable amounts of scheelite as tiny disseminated grains were observed.

On Store Malene scheelite has been found in a variety of rock types such as banded amphibolites, hornblendites, mica-rich metasediments, calc-silicate lenses, and in tourmalinites. Rare examples of minor scheelite veins in the gneisses have been seen. The scheelite in the amphibolites occurs as millimetre-sized disseminated grains, as millimetre-sized grains arranged parallel to the banding, centimetre-sized porphyroblasts, and in folded quartz veinlets.

In the Store Malene area several scheelite-bearing hornblendites have been found. The hornblendites are rarely more than a few tens of centimetres wide and can be traced for a few tens of metres along strike. In these rocks up to $5 \mathrm{~mm}$ large scheelite grains occur, mostly evenly distributed. 
In the banded amphibolites small lenses of scheelite-bearing calc-silicate rocks occur. They are rarely more than one metre long and a few tens of centimetres wide. They locally contain appreciable amounts of scheelite, mainly semi-massive and as centimetre-sized porphyroblasts.

Scheelite-bearing tourmalinites occur on different scales from a few millimetres up to one metre thick. They can be traced for several hundreds of metres along strike. In these rocks scheelite occurs as centimetre-sized crystals and as large evenly distributed grains. Several of the scheelite-bearing tourmalinites are slightly rusty due to small amounts of pyrrhotite and chalcopyrite.

Mica-rich metasediments with scheelite are not common, but when scheelite does occur it is mostly seen as thin coatings on foliation planes.

The scheelite in the Malene supracrustals is generally bluish fluorescent with a small content of molybdenum. Some of the porphyroblasts, however, display a white fluorescence indicating molybdenum contents of up to $0.5 \%$. In a few calc-silicate lenses yellow fluorescent scheelite grains with a molybdenum content in excess of $5 \%$ have been observed. Locally there are veinlets with scheelite grains displaying zoning. Some of the scheelite grains have a bluish fluorescent core surrounded by a white to yellowish fluorescent rim, whereas others show the reverse trend.

\section{Conclusions}

The scheelite mineralisations in the Malene supracrustals are clearly stratabound and not related to the pegmatites. They are furthermore associated with small horizons of iron-formation (Appel, 1983b) and with layers of tourmalinites and sulphides. All field evidence found so far thus supports a syngenetic submarine exhalative origin of the scheelite as suggested by Appel (1985).

Acknowledgements. The authors are grateful to Charlotte Clausen, Hans Kristian Olsen and Jan Sangstad for their valuable assistance in the field and to E. Leonardsen, Geological Institute, University of Copenhagen, for X-ray determination of scheelite.

\section{References}

Appel, P. W. U. 1983a: Tungsten in the Godthåb area, West Greenland. Rapp. Grønlands geol. Unders. $115,59-63$.

Appel. P. W. U. 1983b: Mineralisations in the Malene supracrustals in the Godthåb area, West Greenland. Rapp. Grønlands geol. Unders. 115, 64-67.

Appel, P. W. U. 1984: Tungsten mineralisation in the Godthåb area, West Greenland. Rapp. Grønlands geol. Unders. 120, 51-54.

Appel, P. W. U. 1985: Strata-bound tourmaline in the Archaean Malene supracrustals, West Greenland. Can. J. Earth Sci. 22, 1485-1491.

Beech. E. M. \& Chadwick, B. 1980: The Malene supracrustal gneisses of northwest Buksefjorden: their origin and significance in the Archaean crustal evolution of southern West Greenland. Precambrian Res. 11, 329-356.

Bridgwater, D., Keto, L., McGregor, V. R. \& Myers, J. S. 1976: Archaean gneiss complex of Greenland. In Escher, A. \& Watt, W. S. (edit.) Geology of Greenland, 18-75. Copenhagen: Geol. Surv. Greenland. 
Chadwick, B. \& Coe, K. 1983: Descriptive text to 1:100 000 sheet Buksefjorden 63 V.1 Nord, 70 pp. Copenhagen: Geol. Surv. Greenland.

Dymek, R. F., Weed, R. \& Gromet, L. P. 1983: The Malene metasedimentary rocks on Rype $\varnothing$, and their relationship to Amitsoq gneisses. Rapp. Grønlands geol. Unders. 112, 53-69.

Friend, C. R. L., Brown, M., Perkins, W. T. \& Burwell, A. D. M. 1985: The geology of the Qôrqut granite complex north of Qôrqut, Godthåbsfjord, southern West Greenland. Bull. Grønlands geol. Unders. 151, $43 \mathrm{pp}$.

McGregor, V. R. 1973: The early Precambrian gneisses of the Godthåb district, West Greenland. Phil. Trans. R. Soc. Lond. A 273, 343-358.

McGregor, V. R. \& Mason, B. 1977: Petrogenesis and geochemistry of metabasaltic and metasedimentary enclaves in the Amîtsoq gneisses, West Greenland. Amer. Miner. 62, 887-904.

Nutman, A. P. \& Bridgwater, D. 1983: Deposition of Malene supracrustal rocks on an Amîtsoq basement in outer Ameralik, southern West Greenland. Rapp. Grønlands geol. Unders. 112, 43-51.

\title{
Tungsten exploration in the southern part of the Godthåb area, West Greenland
}

\author{
Peter W. Uitterdijk Appel
}

Recent work by the Geological Survey of Greenland (GGU) in the Godthåb (Nûk) area has revealed a large tungsten province with extensive scheelite mineralisation in the Archaean Malene supracrustal rocks (Appel, 1983, 1984). In the area between Godthåb and Frederikshåb Isblink several large supracrustal amphibolite belts occur (fig. 1). These are presumably of the same age as the scheelite-bearing Malene amphibolites of the Godthåb area (Bridgwater et al., 1976). It was therefore decided to carry out a regional stream-sediment sampling programme in the area south of Godthåb, and this was accomplished in the summer of 1985. The aim of the programme was mainly to find scheelite, but the samples will subsequently be analysed for a number of other elements such as $\mathrm{Cu}, \mathrm{Pb}$ and $\mathrm{Mo}$.

The following report is mainly based on field observations. Laboratory work is confined to $\mathrm{X}$-ray determination of scheelite in three heavy mineral concentrates.

\section{General geology}

The geology of the area has been described by Bridgwater et al. (1976) and the reader is referred to that paper for a detailed account.

The most important rock-forming events in the area were the formation of the Amitsoq and Nûk gneisses. The Amîtsoq gneisses, which contain inclusions of Akilia supracrustal rocks, are the oldest, with isotopic ages of $3700 \mathrm{~m} . \mathrm{y}$. (Michard-Vitrac et al., 1977). The Nûk gneisses, which contain extensive outcrops of Malene supracrustals, are of the order of 3000 to 3200 m.y. old (Chadwick \& Coe, 1983). Contemporaneously with the Malene su- 